\title{
Participation in the Concept or in the Event: Two Ways of Existence of Human Being
}

\author{
Augustinas Dainys \\ Lithuanian University of Educational Sciences
}

\begin{abstract}
This paper discusses two alternative ways of existence of the human being: participation in the concept of reason and participation in the events of the world. It is argued that the traditional Western philosophy from Parmenides and Plato to R. Descartes, I. Kant, and G. Hegel can be described as the participation in the concept of reason. This tradition is characterized by the goal to assimilate the things of the world by concept of reason and in accordance with a project reason, to change the world. This led to the ecological catastrophe. We can overcome ecological catastrophe successfully only when we change the paradigm and shift to the paradigm of participation in the events of the world. The article is based on A. Badiou's conception of event which is contrasted with Descartes' conception of the event. Argumentation of the article shows the importance of B. Spinoza's monistic philosophy for our epoch, which is struck by the ecological disaster. This philosophy is not characterised by the war between things and thoughts, because both thoughts and things are attributes expressing the same God or Nature and are not in conflict with one another.
\end{abstract}

Keywords: concept, event, dualism, monism, causality, causeless universe

\section{Introduction}

In the Western philosophy, we can track the tradition of thinking, which in the most general way can be called the participation in the concept of reason. For example, the ancient Greek philosopher Parmenides said that "What can be thought is only the thought that it is" (Kirk and Raven 1957, 277). When we go to the new ages and look to philosophies of Kant and Hegel, we discover subordination of reality to the reason and equation of things to thoughts. Hegel said that "What is rational is actual; and what is actual is rational" (Hegel 2012, 20). In the Western philosophy, we see a trend to recognize that the reality is thinking. Such a perception of reality created the modern science and technology, and the latter - the modern world with machines, medicine, computers, and the Internet. However, it also brought the world to the environmental catastrophe. And when we try to overcome it, we see that the Western thinking, represented by Parmenides, Plato, Descartes, Kant, and Hegel, cannot help us, because we see the effort to subordinate the nature to reason and, based on reason, to rework or destroy natural things. In order to cope with the ecological catastrophe, we need a new paradigm of thinking.

This article is written in search of a new paradigm of thinking that would enable people to live in harmony with nature. We could say that the ecological catastrophe began not in the twentieth century, but its roots lie

Augustinas Dainys, Ph.D., associate professor, Department of Education, Lithuanian University of Educational Sciences, Lithuania; main research fields: Ontology and Philosophy of Language. 
deep in the Greek philosophy, in the thinking of Parmenides and Plato. According to the latter, this world of things is a "kingdom of shadows," and we have to overcome it by seeking to participate in the ideas of the reason. But in order to acquire ecological sensitivity, we cannot overcome this world and nature. We must learn to cherish the natural things and to recognize their right to be on the other side of our reason.

Thus, the traditional participation in the concept of reason in this article is contrasted to participation in the event of the world. We are grateful to the fundamental works of Alain Badiou, especially the treatise "Being and Event," which gave us a language to think of an event. According to Badiou formulations, event is a self referent set prohibited by ontology. So, by thinking the event, we go beyond the ontological thinking, which was initiated by Parmenides and Plato. In their thinking, we discovered the early developments that led to the catastrophes of the 20th century.

\section{Phenomenological Exercise: Table Experience}

When I am sitting in my room, I look at this table and I see it as a typical representative of a set of tables, then I do not participate in the reality of this table, but participate in its concept. It is this case I have the idea of table in my mind that I call the concept of table. Usually, when we see a table, we subdue the factual table to its concept, and see not this unique table, but its image in our reason, which is represented by the concept of the table. The meaning of the concept of the table is the general image of all tables, linking features common to all tables. Thus, the meaning of the concept of the table is a set of common characteristics of all tables of the past, present, and future. When the image of my reason intrudes between me and the table, it then imposes itself to my vision of the table. In our minds, we have images of tables. Faced with factual tables, we throw those images into reality, and we see not the reality, consisting of singular distinctive things, but commonalities, and these commonalities in our minds do not allow us to take a look to distinctive things. By participating in the concept of the table, and looking into the factual table from the perspective of the concept the table, which is the commonality, I do not see the table as the unique and singular thing, but I see the thing designed by the concept of the table and the singular existence and uniqueness of which was erased by the general nature of the concept. One can ask, what happens when we experience the wonder? Aristotle said that the wonder is the source of philosophizing. Most of our experience is not philosophical, as it happens in the participation in the concepts of reason and by it covering the singular things. We are not surprised, when we project the images of our reason to reality and see what these images create. In this way, we participate at the offside of the reality. The offside of reality is constituted by participation in the concept of reason. So, if we want to participate in reality, we need to break free from the participation in the concept of reason. The seeing of the table as a unique and singular thing happens when we cease to participate in the table concept and drop out the concept of table. Only when we drop out of the concept of table, a table is seen and experienced directly. Then, the wonder happens. At the level of things, every singular thing is unique and inimitable in the world. Hence, it is sufficient for the consciousness to break free from generalities and walk down to the area of things, and as a result, we shall experience a wonder.

\section{The Unambiguousness of the Concept and Polysemy of the World}

The concept is a general form of the set of entities that are named under this concept, which expresses these entities as a separate class. In other words, the concept is a generality including and combining singular entities. For example, the concept of rose includes the set of all past, present, and future roses of the world. 
Each rose is unique and incomparable, but its concept blurs out the uniqueness of each real rose and creates the general image, which covers all unique and singular roses of the world. This commonality and universality of the concept of rose creates the unambiguousness of the concept of the rose. The concept of the rose unambiguously identifies all roses of the world, no matter what is their variety of real roses of the world: the shape of their bloom, colour of petals, flavour, stem height, pricks, etc. And the world inevitably is polysemous: The multiplicity of its entities is the multiplicity of unique and inimitable entities which, if will look at every of them, do not allow themselves to be generalized. But the reason, in order to navigate in the polysemous world, generalises the polysemy of the world's entities blurring out their uniqueness and combining into the commonality of the concept, and moves along the general and unambiguous concepts. Reason's encounter with the entities of the world is an encounter between the unambiguousness and polysemy. However, reason, a priori, looking at the world through the glasses of concepts, sees the polysemous world unambiguously. We face a rose like the commonality of the all singular roses, covering all the world's roses, rather than unique and singular rose.

Kant in his famous saying, that "thoughts without content are empty, intuitions without concepts are blind" (Kant 2007, 86) demonstrated the mutual dependence between concepts of reason and content coming from the world which gives meaning to concepts, and concepts turn the intuition coming from the world into clear one. Concepts articulate the vision of the world's entities. From the polysemous world given to senses, it creates unambiguous reality of schemes with the help of which a person can orientate in the world. For example, from the polysemous flicker of colours, lines, and shapes in the stream of direct experience, when the reason drops on the world net of concepts, it creates a street leading to the Cathedral, a bell tower and a castle. If there was no unambiguousness of the world created by concepts, a human would be lost in the polysemous Heraclitean flow of experience, which is merely the building materials of articulated world's entities. From it, the reason, with the help of the net of concepts, makes articulated, sculptured, and rational world. Thus, the unambiguousness of concept and polysemy of the flow of experience are two opposite poles. The articulated world crystallises in their interaction, which is the middle between stability and chaos. Concepts of reasons are linguistic forms of entities which are filled with the content of the flow of experience, and when you look at the world in this way, it opens up as an articulated and a harmonious whole. Therefore, it is inevitable to participate in the concept of reasons as glasses are inevitable for a myopic person he wants to orient in the world.

The second statement (Tactatus, 1.1), used by L. Wittgenstein to begin the Tractatus Logico-Philosophicus reads as follows: "The world is the totality of facts, not of things." To this philosopher, facts are what exist outside the reason, and is self-given. The reason forms an image about facts. It is this image is a meaningful thought. In the Tractatus, Wittgenstein was still a naive realist, when he recognised independent existence to the facts. Later, it will not be left in Philosophical Investigations. Our study does not recognize independent status and existence outside reason for the facts. There is no fact as objective takes beyond the subject's reason. The fact is made when the subject names reality. By naming the things, we create objects that are constitutive elements of the facts. Different namings of a fragment of the same reality create different facts. Is the Sun revolving around the Earth, or the Earth revolves around the Sun-it depends on the naming system. Facts are created when the subject names reality, and they are the image of the world created by the subject. In our study, there is no longer duality between the external facts of the world, and the image created about them by the subject. The view of the world created by the subject's naming activity is a fact. Unlike Wittgenstein, we do not think that one can create a picture of facts that are beyond reason. There is a Heraclitus flow beyond the 
denoting power of reason, consisting of the world's primary sensory impressions. Objectivity of facts is only the agreement of the community of scientists on universality of the images of subjects and their validity for all members of the community. Facts are intersubjective images of subjects.

Daily life is most abstract and goes through participation in the unambiguous concepts, because people use pragmatic functions of tools when living. Using a tool, we do not look at it as a unique and singular object because if we tried to look at the uniqueness of that object ever a time when we use it, which transcends its pragmatic function, we simply could not live in our everyday life. For example, a bottle of mineral water in everyday life exists as an abstract function: This is an opportunity to freshen by drinking some mineral water. But as the pragmatic function is exhausted, the bottle is disposed into the sorting bin without even thinking about the opportunity of this one and only object. It is the same with all the daily-use items. We simply cannot allow them to be the one and only, because then we could not function in our everyday life.

Using Deleuze's terms of repetition and difference, one may say that the unambiguousness of the concept, constantly repeated in social practices, creates the ordinary, which functions as unambiguousness. This society reproduces itself forcing its members to keep repeating social norms: be polite, do not steal, will not be violent. These norms of society, when constantly repeated, reinforce the society. And individuals who refuse to repeat them, are disciplined and punished. Changes in society and revolutions occur as differences in the repetitions of unambiguousness. Innovation comes to the society through difference in repetition. Innovation, as a break in the ordinary, is an event. It interrupts casualness by opening the novelty. In a long run, the society absorbs this event as a novelty in casualness and turns into a norm. Therefore, it turns into repetition, creating casualness. This continues until the next innovative event as a difference in repetition.

We now come to the second topic of the article-participation in the event. But at first we should discuss the existing ideas of event of Descartes and Badiou.

\section{Ideas of Event by Descartes and Badiou}

We can distinguish between two types of event: the Cartesian and the Badiou ideas of event. The Cartesian idea of event stems from the hierarchy of reality and the difference between res cogitans and res extensa, the thinking and the extended substances, when the extended substance obeys to the command and authority of the reasoning substance. The direct consequence of this authority is the event in the world: whether it is a moved hand which movement was commanded by my reason, or a planted or a cut tree as a direct consequence of the thought project. Cartesian events-are the implemented projects of thoughts in the world turning into rationally changed positions of things of the world. We will call this concept a rough concept of the event, because it is the implementation of the rational project of thoughts in the world through radical transformation. Ecological catastrophe that struck the world, was due to the fact that the mentality of the global industrialized societies is largely Cartesian. This way, it was mastered even by the societies which are not directly Western. The Western industrial revolution, that later also conquered the Asian continent, testifies that the West has spread the Cartesian, or consequential paradigm of thinking and acting in the world.

Cartesianism is a philosophical paradigm, in which as a consequence of the duality of thinking and extended substances or between thoughts and things, is created a discord between thoughts and things. Thoughts want to assimilate the things of nature by converting them into the equivalent of the implemented project of thoughts. Nature is foreign to the thinking, but the reason wants to change natural things in order they correspond to the order of reason. For example, in the late Soviet period the Soviet Union's government has 
conceived a plan to change the direction of the Siberian rivers. This way, water from the northern seas would be supplied for agriculture to the south. Only because of collapse of the Soviet empire, its authorities could not implement this project. If this were done, it would be a global ecological catastrophe. So the reason creates projects of thoughts and transforms nature, in order to correspond nature to these projects. Reiterating, once again we can say that the Cartesian event is rough, because it is a thought transformed into action, and an action is transformed into an object with an artificial status. A Cartesian event is a bridge that connects the reason and the body (the thing). The most famous proponent of the Cartesian concept of the event in the analytical philosophy of the twentieth century was Donald Davidson.

Davidson considers the change in the state of things of the world to be an action, having its reason-rationalisation of mind which we shall call simply the intention corresponding the action. Therefore, action is an event having its explaining thought or intention. Intention accompanying the action distinguishes it from chaotic movements, which we do not consider an articulated action. Davidson gives an example:

I flip the switch, turn on the light, and illuminate the room. Unbeknownst to me, I also alert a prowler to the fact that I am home. Here I need not have done four things, but only one, of which four descriptions have been given, I flipped the switch because I wanted to turn the light and by saying I wanted to turn on the light I explain (give my reason for, rationalize) the flipping. But I do not, by giving this reason, rationalize my alerting of the prowler nor my illuminating of the room. (Davidson 2001, 4)

Thus, according to Davidson, any movement is made an action, and is demarcated from chaotic movements by its intention which rationalises the agent's movements by turning them into articulate action. But for us it is important that the action is an intentional event, which has the task of changing the state of the world's things. In analysing the action, you can distinguish: (1) the intention to change any state of the things in the world, (2) the initial position of the state of things in the world before change, and (3) position of state of the things in the world changed by intentional action. But it is possible to have not a rational action happening in the world and changing it according to the preliminary intention, but spontaneous participation in reality, turning into an unforeseen event which radically changes all previous provisions, convictions, and beliefs of the subject, turning it into a new subject whose further life will spread as a loyalty to the event that took place. At this point, we move to "French Russell's" Alain's Badiou's idea of the event that we call subtle.

Badiou's ontology is outlined in the fundamental treatise "Being and Event" based on the mathematical set theory, which initially was developed by Georg Cantor. Subsequently, it was continued by other mathematicians. Cantor found a way to describe the infinite multiples in the mathematical language (there is not one but many infinities). One of the Cantor's basic ideas can be formulated as follows: The set of subsets in each set is bigger than the set itself. If there are five apples on the table, there will be 32 options of combinations of five apples out of these, when a group is any set of those apples. Thus, 32 is greater than 5 . In the first decade of the 20th century, the set theory was one of the most debated mathematical theories. The pioneer of analytical philosophy Bertrand Russell also participated in this discussion. His contribution to the theory of sets is the claim that the set cannot be its own element. He published these insights in the treatise "Mathematical Logic as based on the Theory of Types" issued in 1908 (Russell 2007). In this treatise, Russell considered the liar's paradox. The statement of Epimenides the Cretan that all Cretans are liars, applies to the statement of Epimenides the Cretan who says this statement, therefore, it must be admitted that Epimenides the Cretan is lying, by saying that all Cretans are liars. Such a statement of Epimenides the Cretan is the case of a set, which is its own element. Vividly describing the Russell's paradox, we can say that the building is built from bricks, but a separate brick 
is not a building. Russell sought to address the liar paradox by creating the theory of types, with the main idea - to create a hierarchy of different types of statements. The statement of Epimenides the Cretan that all Cretans are liars, is not the same type of statement as statements of other Cretans who are accused of being liars, because in the hierarchy of types he is one level higher than the claims of the Cretans. In this way, we avoid the set, which is the element of its own.

Badiou says that "mathematics is the thinking of being as being" (Badiou 1998, 55). The major innovation of the Badiou's ontology is the application of mathematical theories in reflection of being. As a thinker of being, in this regard he is not the epigone of $\mathrm{M}$. Heidegger who had raised a task to remember the being, because Badiou found a new approach of access to the thinking of being. Heidegger was using affirmations of poets as testimonies of the truth of being, while Badiou used the mathematics claiming that mathematics is ontology. As a thinker of event, Badiou argues that ontology prohibits the event. Event always happens on the other side of being, therefore, according to the original words of Badiou, event is a trans-being (trans-être).

Badiou presented the mathema of event. This is the inversion of the Russell's requirement that the set cannot be its own element. The event, according to Badiou, is self referental set, underlying itself-a set which is the element of itself. Here we present the simplified mathema of Badiou's event: $\mathrm{X} \in \mathrm{X}$. It should be read as follows: $\mathrm{X}$ belongs to $\mathrm{X}$. The concept of event by Badiou is based on the self reference of reality. The event is born from it. Badiou's event refers to itself as the only reality and the grounds supporting it. From the other side, the mathema of the Russell's requirement can be formulated as follows: $\mathrm{X} \notin \mathrm{X}$ and can be read as follows: $\mathrm{X}$ can not belong to X. If we follow the Badiou's view that mathematics is ontology, in this respect the Russell's theory of types is the theory of being which forbids the event.

Badiou event is not determined by causes, as is characteristic of Descartes event. Badiou's universe is not a causal universe with prevailing events determined by causes. In nature, there are various blind causalities influencing events. However, natural events with their causes are not events in the true sense of the word. Badiou's event's horizon is history. He refuses to explain the historical event in social, economic, cultural, or psychological causes. History is a relation of events that are contrary to natural cycles: such as the emergence of the Greek democracy or philosophy, the French Revolution, the Paris Commune or the student revolts of 1968. Every event reveals the singular truth. Therefore, participant in reality of event only has to commit to the event that has happened, as Plato did after Socrates' trial, committing to the person of Socrates, or the apostle Paul who committed to the event of Christ in the face of Christ's resurrection. Therefore, even though Badiou does not say that, the event is a miracle that reveals a singular truth. This miracle can happen only on the other side of existence, which forbids the event. So, when thinking the event, assumptions of ontological thinking are not suitable. Ontological thinking is an organic thinking, thinking reality as an organism whose parts and organs are bound by ties of dependence and are in tune with each other. Meanwhile, Badiou's thinking of event that happens on the other side of being, is historical and sociable. Badiou's event happens as establishing history and sociability. Badiou applies Marxism and Maoism as a method of thinking the history and as the horizon of events. The latter at first glance looks like an outrage or eccentricity of a strange professor of philosophy, but if we think about this philosophy of event, this curiosity appears as the consistency of the philosopher of event.

We called the Badiou's idea of event subtle. According to it, the event just happens. It is an adventure that cannot be foreseen. For the Cartesian idea, the thought, that will turn into action in the future, is a cause of this action as the event. To understand the event is to understand its cause. But, according to Badiou, the event has 
its own cause: The event is a set, which is its own element. When an event appears, it appears from nothingness and goes into nothingness. It cannot be reduced to an idea as a cause of event. Thus, under the subtle concept, event it is an adventure that cannot be foreseen. It does not have any cause like the Cartesian idea of the event, when it is decided to change the direction of the river flow and the flow is changed. This more resembles the emergence of Greek democracy, which is a miracle. The emergence of Greek democracy is a subtle event. It just happened, it is a mystery. It should be just accepted. Meanwhile, economic, sociological, historicist interpretations simply vulgarise this event.

The Cartesian paradigm is constantly struggling between thoughts and events. The reason wants to bring together a variety of things to the unity of reason. But this united dimension of reason is foreign to things that are unique and singular. The reason wants to conquer the reality of things, because things are alien to it. Thinking wants to occupy nature, but nature in own way seeks to slip away from such efforts of reason. Hegel turned this destruction into a philosophical principle by creating the concept of negativity. In Hegel's philosophy, negativity forces self-consciousness to move towards absolute knowledge. During this movement, the reason overcomes individual things and becomes absolute knowledge. Western philosophy was alien and hostile to nature, wanted to conquer it. The Cartesian concept of the event, which subordinates the event with the causes of reason, and does not allow the event to be spontaneous and unexpected, as a consequence subordinates the nature to the reason. Such a way of thinking brought the modern world to an environmental catastrophe. The origin of ecological catastrophes is purely western, therefore, this philosophy must assume responsibility for environmental catastrophes, as science emerged from philosophy, and technology, which transforms the world by destroying nature emerged from science.

\section{Event as a Short Circuit in Being}

After explaining the Cartesian and the Badiouian ideas of the event, we will present our own concept of the event, which is a further development of the idea of the event by Badiou. To list the insides, we will use the traditional Christian tomistic hierarchical scheme of existence borrowed from Aristotle. The lowest hierarchy of being are minerals, above them are plants, then animals, still above the human, then angels, called pure intelligence by Thomas Aquinas, and the highest for all, as the pinnacle of the hierarchy of being is the God. Using the author's terms, the event is a short-circuit in the being, when a connection takes place between two different levels of the hierarchy of being. For example, following the Christian dogma, Christ's birth is an event on the other side of being, since through the birth of Christ, the levels of the God as the apex of the hierarchy of being, and the human as a lower level of the hierarchy, were short-circuited: according to the Christian theology, Christ is a perfect God and a perfect man in one. Being forbids a man to be God and requires to occupy a decent place between animals and pure intelligences. Identity of God and human —is an event on the other side of being, and it is prohibited by the hierarchy of being, where God and human have their place, and it can be implemented only upon going to the other side of existence. Another such a short circuit in the hierarchy of existence is the claim of St. John in the prologue of Gospel, that the Word of God is God. The Word and the God are the entities not of the same dimension, however, their identity creates the event of Christianity which is Christ. Metaphorically speaking, the event will be a miracle, when, looking at the bricks from which the house is built, you in one brick will find the same house. The house in the break is its own element, and it is prohibited by the ontology. 
In order to better contemplate the mystery of the event, it is worth drawing a distinction between the event of the being and the event on the other side of being. The event of being is not an event in primordial sense, but blind necessity. For example, pikes feed on smaller fish, but when they ingest a roach, there is no event, but the necessity blind of being. This event of being which we do not treat as event stems from the laws of nature. What happens according to the laws of nature are not the events, because they were determined by the necessity of being. Still in other words, when a pike swallows a roach, there is no history, because it is not a singular event but the event that obeys the laws of nature. Meanwhile, the event is what comes out and is released from the tyranny of the laws of nature. If a miracle happens and the pike start speaking, asking to let her go into lake by fulfilment of wishes, as is the case in a fairy tale, that would be an event. It would be one time, and would happen on the other side of the laws of nature, therefore that it would not be the event of being, but the event on the other side of being. Being and nature's laws prohibit the pikes to speak with a human voice, but if in spite of being in blind necessity the pike start talking, it would be a miracle, and the event that has freed itself from the power of the laws of nature. Pike's talking would be a short-circuit between the hierarchy levels of the animal and the human, because the animal suddenly acquires human properties and would be an animal and a human in one. This is what a miracle is.

The same miracle is the invention of the Greek democracy with prevailing tyrannies all around. Hierarchy of being prohibits the event. It is based on the tyranny of higher levels of the hierarchy of being towards lower levels of the being hierarchy. Therefore, tyranny stems from the arrangement of being when a separate individual is subordinated to the higher level of the hierarchy of being. Barbara Cassin, reviving the thinking of Sophists rejecting the platonic and Heideggerian ontological thinking and on this basis defending the democratic multiple, as an anti-democratic feature, reveals that Plato perceived pole as a soul, whose abilities form an integrated hierarchy: lower parts obey the higher authority (Cassin 1992, 126). Cassin calls such model of the pole organic, and associates with ontology. The model of being is an organism that lives only because of the subordination of its parts and organs. It is no coincidence that the greatest ontologist of the ancient world Plato, and the greatest ontologist of the new world Heidegger supported tyrannies. Such a gesture of them was caused by a desire to subordinate the individual to being. Meanwhile, this subordination is forced. And both of them justified social violence, which is an equivalent to the hierarchy of higher forms of violence towards lower forms of hierarchy. That is why Plato was the opponent of the democracy of Athens. Being prohibits democracy and individual's self-determination. The invention of democracy in ancient Greece was an event on the other side of being. Individual's self-determination can also take place only on the other side of existence, which is blind necessity. According to Cassin, the opposite to the organic models being is a picnic- $\mathrm{a}$ free festival of free people (Cassin 1992, 131). This festival reflects the people's democratic state and is an event on the other side of being.

The event is a lightning of being that illuminates the history by manifesting the singular truth. Lightning is a short circuit, a discharge of clouds having different charges, and the event is the discharge of charges accumulated in daily life. By becoming the event, it manifests the singular truth, the accumulation of which is history. It is necessary to distinguish big and small events. The major event has a meaning to the entire human community. An example of such an event could be the invention of democracy in ancient Greece. Identity of modern Western countries is defined by the event of fidelity to the Greek democracy. A minor event has meaning in the life of an individual human. An example of such an event could be the appearance of Christ to the Christian persecutor Saul on the way to Damascus. According to Badiou, the human subject is constituted 
by fidelity to the event that has changed him. This way, the Christian persecutor Saul, upon the appearance of the vision of Christ, committed to this event and became the apostle Paul. This commitment was a turning point in the Christian persecutor Saul's life, he changed his views and lifestyle. Upon committing to the event, Paul became a subtle politician of the early Christian church, and a promoter of the Christian message, the so called "apostle of nations." He devoted his further life for missionary journeys and writing letters, which were included in the Christian canon. This activity contributed to the fact that Christianity in the early centuries AD acquired the status of the dominant religion in the Western world.

\section{Participation in the Event of the World}

We will begin this section with the description of participation in the event from Marcel Proust's novel Swann's Way, the first part of the famous series of seven novels, "In Search of Lost Time."

The childhood of Marcel, the major character of the M. Proust's series of seven novels "In Search of Lost Time” was spent by living through the farewell kiss drama of his mother in the evenings. He wanted very much his mother to kiss him in the evening before sleep, but she, in turn, was often busy-interacted with the family guests and not always had enough time to do it. One could say that the young Marcel had an intrusive idea - the evening kiss from his mother, and until it was turning into reality, he could not be happy and fell asleep. This obsession idea is a consequence of Marcel's participation in the concept of the evening kiss. The concept of the evening kiss with participation of Marcel, would turn into reality, when he managed to call his mother, and force to kiss him. So his mother's evening kiss is a Cartesian event the idea of which were called quite rough because it takes place when the unambiguousness of the concept makes the world unambiguous, or, in other words, in order the event of the world which in certain sands stems from the violence of the subject to the world, because the world is forced to correspond to the concept of reason, or correspond to that concept in the head. Here, from participation in the concept we move to the participation in the event (kiss), but in this case the participation in the concept is the cause of participation in the event of the world. The participation in the concept is linked with participation in the event of the world by causal connection. This is the causal concept of event. However, Proust describes an event of completely different nature, which is no longer Cartesian but more in line with the subtle to idea of the event.

Many years had elapsed during which nothing of Combray, except what lay in the theatre and the drama of my going to bed there, had any existence for me, when one day in winter, on my return home, seeing that I was cold, my mother, seeing that I was cold, offered me some tea, a thing I did not ordinarily take. I declined at first, and then, for no particular reason, changed my mind. She sent for one of those squat, plump little cakes called "petites madeleines," which look as though they had been moulded in the fluted valve of a scallop shell. And soon, mechanically, dispirited after a dreary day with the prospect of a depressing morrow, I raised to my lips a spoonful of the tea in which I had soaked a morsel of the cake. No sooner had the warm liquid mixed with the crumbs touched my palate that a shiver ran through me and I stopped, intent upon the extraordinary thing that was happening to me. An exquisite pleasure had invaded my senses, something isolated, detached, with no suggestions of its origin. And at once the vicissitudes of life had become indifferent to me, its disasters innocuous, its brevity illusory - this new sensation having had the effect, which love has, of filling me with a precious essence; to feed mediocre, contingent, mortal, Whence could it have come to me, this all—powerful joy?...

And suddenly the memory revealed itself. The taste was that of the little piece of madeleine which on Sunday mornings at Combray (because on those mornings I did not go out before mass), when I went to day good morning to her in her bedroom, my Léonie used to give me, dipping it first in her own cup of tea or tisane... 
And as soon as I had recognized the taste of the piece of madeleine soaked in her decoction of lime-blossom which my aunt used to give me (although I did not yet know and must long postpone the discovery of why this memory made me so happy) immediately the old grey house upon the street, where her room was, rose up like a stage set to attach itself to the little pavilion opening on to the garden which had been built out behind it for my parents (the isolated segment which until that moment had been all that I could see); and with the house the town, from morning to night and in all weathers, the Square where I used to be sent before lunch, the streets along which I used to run errands, the country roads we took when it was fine. (Proust 1996, 52-55)

In this passage, Marcel describes the event, fateful to him as a writer, when one day in winter, as he came home cold, his mother offered him some tea, affair that he did not ordinarily take; with little cakes called petites madeleines. Weary after a dull day, mechanical and reluctantly, he raised to his lips a spoonful of the tea in with a soaked morsel of the cake. No sooner had the warm liquid touched his palate than a shudder ran through his whole body, he shook and started listening. Here was the event that we could refer to as one of a higher reality, equivalent to the experience of love. Marcel says that for no cause he was overwhelmed with extraordinary pleasure. For us it is important that this event was not stepping from the concept of participation to the event of the worlds, what we call Cartesian or causal concept of event. The event, on the contrary, was unforeseen and unexpected, like a revelation.

A rough causal concept of event provides an opportunity to force the event to happen in the world. Andre Breton said that imagination is what tends to become a reality. To paraphrase Breton, in the case of rough concept of event it happens that the imagination, with which the subject provides positions of the objects of the world, turns into reality by the subject manipulating positions of the objects of the world. Meanwhile, the subtle concept of event accepts the event as a fate which cannot be imagined and predicted. It simply happens. And just because the subject did not foresee this event, it enriches the subject by revealing the singular truth. To Marcel, this singular truth became the linking idea of his series of novels - the search for lost time, when the event, as if a knocked billiard ball, invite of the events, or metaphorically speaking, collides with other billiard balls and causes them to move. Marcel, after tasting tea and cake, remembered that his aunt has treated him in childhood with exactly the same cake and tea. The memories caused to remember the whole world of childhood. Upon becoming a writer, Marcel committed to this event unforeseen in any way, and turned the remembrance of past events into a novel writing method. So, this event happened as the revelation of the gift of destiny that Marcel could not imagine and predict in advance.

The actual event is some object that happened unexpectedly. You can always ask why a certain event has happened: a flash of beauty, a newly met person, an unexpected idea that came to the head, or social change? One can always think of some causes, or adapt causal schemes to the event, but if you look more attentively, it becomes clear that the chain of causes can be endless. Therefore, in order not to lead the mystery of event slip your eyes, one has to stop the chain of causes and suggest that the event just happened or appeared. It just happened, and there is no deduction or induction of the chain of causes. The event appeared within itself. So many things happen in the world, and all of them are intertwined into a complex knot, therefore, it is unwise to talk about causes of events, but one has to talk about the destiny of a human, city, country, culture or civilization. So linden tea offered to Marcel by his mother, with petite madeleine cakes, tasting which brought him to the maze of memories about the last time, was a gift of the fate. It cannot be explained by applying causal psychological, literary, sociological, cultural, or historical patterns. Event is what happens and creates the destiny of the human or the entire human community. The most correct relation with the event is to look at 
it as a miracle, taking beyond causal schemes, reduction models and allowing to penetrate into the mystery of being in the world.

\section{Positivity in Respect of the World}

The epoch turning point of modern philosophy is marginalization of the thing in itself to the distance that took place in Kant's philosophy, by recognising that the thing in itself is unknowable. This turning point in Kant's philosophy has gained even greater scale and momentum in the following Hegel's philosophy, which abolished the Kantian thing in itself, and recognised that only transition of givingness created by negation of the world by the consciousness, and negatively moving towards self-awareness, are accessible to consciousness. Hegel's philosophy of negation and negativity has intrinsic romantic wisdom-the recognition that reality surrounding the person may not satisfy the deepest and most essential human spiritual needs, therefore all one can do is to deny this reality and build own identity by distancing oneself from reality and plotting own limits through the rejection of reality. However, how Marx read and understood Hegel led to the entire modern mentality. Marx in his "Theses on Feuerbach" argued that "philosophers have only interpreted the world in various ways; the point, however, is to change it” (Marx 1998, 574). Man no longer can avoid responsibility for the reworking the nature of the world, for consumption and industrial destruction directly led to the ecological catastrophe. In order the consciousness of our epoch becomes environmentally sensitive and assumes responsibility for the surrounding world, we need to change the paradigm of thinking: to transition from negativity in relation to the world towards positivity. We understand the idea of positivity as opposition of the idea of negativity and do not link positivity to the philosophical trend of positivism. To the author of the article, positivity in relation to the world is ethical, not an epistemological category.

Therefore, in order to live in harmony with nature, we have to change the paradigm. We need a paradigm of reality that allows to live a life without negativity, because negativity arises of dualism between reason and things, when reason seeks to subdue objects to reason. This subordination is destruction of objects. We need a paradigm of reality which avoids a strife between objects and reason. For this purpose, we have to reject the dualistic paradigm of reality which avoids a breaking down into the reasoning and extending substances, and accept a unitary paradigm of reality not characterised by conflict between the thoughts of reason, and things of the world that has penetrated the entire modern philosophy.

In addressing this problem, it is worthwhile to remember and make relevant the monistic Spinoza's philosophy criticised for its lack of the concept of negativity, which is characteristic to the philosophy of Hegel, allegedly more advantageous than Spinoza's philosophy. However, this apparent lack of Spinoza's philosophy turns to its advantage, when viewed in the spirit of today's era, which says that we no longer can dissociate ourselves from the world by denying it. The task of our epoch is to accept and love the world by taking responsibility for it. Spinoza is not a philosopher of criticism, pessimism, irony, denial or dissociation, but the philosopher of joy about the world. He is joyous about the contemplation of God, which is Nature. We, in our terms, will say: when, moving from the unambiguousness of concepts of reason to its participation in the polysemy of the world, we start enjoying the inexhaustible richness of the world, the events of which turn into events of wonder and flashes of beauty.

In his "Ethics," Part II, Proposition 40, Note 2, Spinoza distinguishes three kinds of cognition. The first is distorted knowledge of objects, which Spinoza calls the opinion. The second kind of knowledge is knowledge by reason, from notions common to all men, and adequate ideas of the properties of objects. In our terms, the 
second type of cognition is knowledge through participation in the concept of reason. The third kind is the general knowledge not divided by concepts, called intuitive knowledge by Spinoza. In our terms, intuitive knowledge is a direct participation in the reality of the world of things when no concept link or obstacle suppressing the intuition and interferes between the soul and the world of things. In "Ethics," Part V, Proposition 25 Spinoza says: "The highest striving of the mind, and its greatest virtue is to understanding things by the third kind of knowledge." Spinoza does not use the term of positivity, but speaks of the adequate knowledge of affect (affectus). It helps to overcome the passivity of the soul, consisting of inadequate and vague ideas of affect. Therefore, in "Ethics," Part V, Proposition 15, we read as follows: "He who understands himself and his affects clearly and distinctly loves God, and does so more, the more he understands himself and his affects." Adequate knowledge of oneself and things of the world becomes love of God, who is also Nature. In the proof of this proposition, Spinoza speaks of joy arising from the contemplation of God.

Spinoza broke the dualism of the Cartesian paradigm between nature and thinking. In his philosophy, there is no longer conflict between thoughts and things, because reasoning stems not from dualistic, but from the monistic paradigm. The thought and the thing (thinking and extension) are not two different substances, as is in the philosophy of Descartes, but the attributes expressing the same God or Nature. Adequate knowledge of oneself and things of the world by the third kind of knowledge takes towards the participation in the reality of God or Nature. Spinoza speaks of life, full of joy, arising from contemplation of God, who is Nature at the same time. In this shortage of negativity which is replaced by the joy about the surrounding reality, we have to see the greatness of Spinoza.

\section{Conclusions}

(1) The Western philosophy, from Plato through the Middle Ages to the founder of the modern philosophical paradigm Descartes, was famous by a dualistic understanding of human and the world. For Descartes, reality split into the reasoning and the extending substances. The immortal part of human-the soul—has been synonymous with the reasoning substance, and human body—with extending substance. However, there was an insurmountable boundary between the reasoning and extending substances. The world of nature things was alien to the soul related to thinking, and the things of nature must be by force mastered by the thinking. A consequence of the dualistic conception of human and the world in the West is the ecological catastrophe occurred in the twentieth century, with its roots in Greek, especially in Plato, philosophy.

(2) In order to successfully overcome the ecological catastrophe and develop environmental awareness and sensitivity, it is necessary to change the paradigm of thinking: the prevailing dualistic human model that causes an opposition between thoughts and things, and creates the desire of thoughts to alienate, modify, and redo things, should be replaced with a monistic reality model in which framework the human is no longer an autonomous being in respect of nature and has a reasoning soul alien to nature, but human is an intrinsic part of the surrounding world and nature.

(3) Participating in the concept, human being is alienated with the world of nature things, and conceives them as generalities, which covers the singularity and uniqueness of the things, and cannot experience flashes of beauty and wonder of the things. Participating in the event of reality, when concepts of things do not intrude between mind and the things of nature, human experiences singularity and uniqueness of nature things.

(4) We can distinguish the Cartesian causal universe in which every event has its own cause, and noncausal universe of Badiou where event is its own element, forbidden by being and happening beyond it. In 
this case, the cause of the event is a mystery that cannot be explained by sociological, historical, economic, and other causal schemes. The emergence of the Greek democracy is the subtle event, which emergence is a mystery and is only vulgarised by various causal explanations.

(5) When attempting to overcome the ecological catastrophe, the monistic philosophy of Spinoza becomes relevant. Critics note that this philosophy lacks the concept of negativity; the concept that characterizes the philosophy of Hegel. However, this shortage of the concept of negativity is the advantage of Spinoza's philosophy. His philosophy is characterized by positivity towards the world. Spinoza does not deny the surrounding reality, but seeks adequacy in respect of it. Spinoza's relationship with the world is characterized by joy, coming down from the contemplation of God, or Nature. Spinoza happily accepts events of the world, rather than distances himself from them, plotting his "I" boundaries through rejection of the surrounding reality.

\section{Works Cited}

Badiou, Alain. L'être et l'événement. Paris: Seuil, 1988.

---. Court traité d'ontologie transitoir. Paris: Seuil, 1998.

---. Saint Paul: The Foundation of Universalism. Trans. Ray Braisser. Stanford: Stanford UP, 2003.

Cassin, Barbara. “De l'organisme au pique-nique. Quel consensus pour quelle cité?” Ed. Barbara Cassin. Nos Grecs et leurs moderns. Paris: Seuil, 1992. 114-48.

Davidson, Donald. Essays on Actions and Events. Oxford: Oxford UP, 2001.

Descartes, René. Meditations and Other Metaphysical Writings. Trans. D. M. Clarke. London: Penguin, 2003.

Hegel, Georg. Elements of the Philosophy of Right. Trans. H. B. Nisbet. Cambridge: UP, 2012.

Kant Immanuel. Critique of Pure Reason. Trans. Marcus Weigelt. London: Penguin, 2007.

Kirk, Geoffrey and Raven, John. The Presocratic Philosophers. Cambridge: Cambridge UP, 1957.

Marx, Karl and Engels, Friedrich. The German Ideology. Amherst, New York: Prometheus Books, 1998.

Russell, Bertrand. Logic and Knowledge. Nottingham: Spokesman, 2007.

Proust, Marcel. In Search of Lost Time I. Swann's Way. Trans. C. K. Scott Moncrieff and Terence Kilmartin. London: Vintage, 1996.

Spinoza, Benedict. Ethics. Trans. E. Curley. London: Penguin, 1996.

Wittgenstein, Ludwig. Tractatus Logico-Philosophicus. Trans. D. F. Pears and B. F. McGuinness. London and New York: Routledge, 2001. 